\title{
A magaspontok és levezetett pontok pótlásáról és ellenốrzéséról
}

\author{
Busics György - Tóth Zoltán - Tóth Sándor
}

DOI: $10.30921 / G K .73 .2021 .1 .3$

Absztrakt: A magyar vizszintes alapponthálózatban számos magas építményt határoztak meg alappontként (magaspontként), örhálózatot és levezetett pontot is létrehozva a terepszinten. Az ilyen típusú alappontok elmozdulásának vizsgálatakor és pótlásakor több kérdés merül fel, amelyek megválaszolását példák segítségével mutatja be a cikk, kiemelve a magaspontra végzett távmérés és a kiegyenlitố számítás szerepét. Napjainkban is több magaspont (elsôsorban templomtorony) felújítása folyik, ami a téma aktualitását jelzi.

Abstract: There are some high buildings in the Hungarian horizontal national network existing as geodetic points supplemented with guard points on terrain level. If we want check the movement of such points or replace them, the authors present examples, highlighting the role of distance measuring and network adjustment. High points (especially church towers) are still being renovated todays, this also indicates the actuality of the topic.

Kulcsszavak: vízszintes alapponthálózat, geodéziai magaspontok, ôrpontok, alappontpótlás

Keywords: horizontal geodetic network, geodetic high points, guard points, replacement of fixpoints

\section{Bevezetés: a magaspontok elônyérốl és hátrányáról}

Magaspontnak nevezzük egy magas építmény azon elméleti pontját, amelyet vízszintes geodéziai alappontként meghatároztunk. Az elméleti pont az építmény valamely geometriai alakzata (henger, gömb, csonka kúp) függólegesnek tekintett tengelye és egy adott magasságban képzelt vízszintes sík metszéspontja. Tipikus magaspont a templomtorony és a gyárkémény, de számos kilátót, víztornyot, vártornyot, adótornyot is meghatároztak geodéziai alappontként. Templomtorony esetében a keresztet vagy a csillagot tartó gömb alatti henger felsố tengelypontja az elméleti pont, vagyis ez a vízszintes irányzás helye. Rövid irány esetén a henger (,gömb alatti nyak”) bal és jobb szélére olvasunk le irányértéket, majd ezeket közepelve kapjuk az elméleti pontra vonatkozó irányértéket. A magaspontok valamely (szintén elméleti) pontjának a magasságát is megadják; templomtornyok esetében ez többnyire a gömb közepe. Aki kiválasztja és alappontként meghatározza a magaspontot, a pontleíráson pontosan megadja a vízszintes és magassági értelmú irányzás helyét, amit a késôbbi méréskor is követni kell.

A magaspontoknak a múltban (amikor nem GPS-technikával, hanem irányméréssel, illetve irány- és távméréssel történt az alappontsứrítés) több elônye volt. Ilyen előny az állandósítás költségének megspórolása, hiszen csak ki kell választani egy, a célra megfelelố építményt. Egy komoly építmény várhatóan hosszabb távon fennmarad, mint egy kôvel állandósított alappont. További elôny, hogy a magas építmény sok helyrôl, távolról is jól látható, azaz tájékozó pontnak felhasználható anélkül, hogy oda külön irányzandó pontjelet kelljen vinni és ôrizni.

Hátrányként hozható fel, hogy a nem megfelelően kiválasztott építmények (elsôsorban a nagyon magas, karcsú adótornyok vagy kilátók) szél vagy napsütés hatására mozoghatnak. Példaként hozzuk fel a székesfehérvári hôerômú 105 méter magas vasbeton kéményét, következtében naponta 10-15 cm-t képes mozogni. A templomtornyok esetében számolni kell azzal, hogy egy idô után felújításra szorulnak. A toronysisak renoválását manapság gyakran úgy oldják meg, hogy az egész szerkezetet toronydaruval leemelik, a földön újjáépítik, majd visszaemelik. A magaspontok elmozdulásának ellenôrzésére szolgál

\begin{tabular}{|l|c|c|c|c|c|}
\hline rendúség & $\begin{array}{c}\text { összes alappont } \\
\text { (darab) }\end{array}$ & $\begin{array}{c}\text { ebból } \\
\text { magaspont }\end{array}$ & $\begin{array}{c}\text { ebból } \\
\text { torony }\end{array}$ & $\begin{array}{c}\text { ebból } \\
\text { kémény }\end{array}$ & $\begin{array}{c}\text { ebból } \\
\text { egyéb }\end{array}$ \\
\hline elsőrendú & $243^{2}$ & 40 & 40 & - & - \\
\hline harmadrendú & 2171 & 187 & 185 & - & 2 \\
\hline negyedrendú fópont & 5187 & 1046 & 1009 & 20 & 17 \\
\hline negyedrendú & 47672 & 2520 & 1919 & 394 & 207 \\
\hline
\end{tabular}

1. táblázat. Magaspontok száma az EOVA-ban 1 A táblázat aktualizált adataiért köszönet a Lechner Nonprofit Kft.-nek, személyesen Sebôk Tamásnak.
2 Az elsốrendú hálózat kiegyenlítésében 141 országhatáron belüli pont szerepelt. A statisztikában
az elsốrendú (vagy más rendúségú) pontok közé sorolják az anyapontok levezetett pontjait (irány-
pontjait) is.

az ôrhálózat, amelynek kiépítése minden országos alappont esetében előírás volt. Az ôrhálózat minimálgeometriája három pontból áll (két, egymáshoz csatlakozó és egymásra meróleges alapvonal végpontjai), megadva az alapvonal és a magaspontra menô irányok közötti törésszögeket. Ezek a törésszögek „őrzik” a magaspont helyzetét, ezeket tervezték újramérni egy elmozdulás gyanújakor. Az ôrpontok közül kettôt csak föld alatti ôrkôvel állandósítanak, egyet pedig a pont rendúségének megfelelô kôvel (vagy burkolati jellel) a terepszinten. A terepszinti állandósítás célja az volt, hogy a magasponthoz földi méréssel (például sokszögvonallal) lehessen csatlakozni, erről a pontról tájékozó irányt (irányokat) is kellett mérni. Ezt a terepszinti pontot a magaspont levezetett pontjának nevezik, koordinátáit a magaspont-levezetés módszerével számították, pontszáma pedig a magaspont pontszámát kiegészítő / 1 lett. A magaspont-levezetés elnevezés arra is utal, hogy előbb amely napsütés (egyoldalú hőhatás) 
keletkezik a magaspont koordinátája (a rendûségnek megfelelô hosszúságú meghatározó irányokból), majd ennek ismeretében, utóbb számítjuk ki a levezetett pont koordinátáit.

Az Egységes Országos Vízszintes Alapponthálózat (EOVA) mindegyik rendû́ségi osztályában szép számban találhatók magaspontok (1. táblázat).

\section{Magaspontok elmozdulásának vizsgálata}

Az őrhálózat adatait az EOVA magaspontjai esetében külön törzslap és helyszínrajz tartalmazza, ennek elvi vázlata az 1. ábrán látható. A magaspont esetleges elmozdulása az ôrhálózati törésszögek újramérésével vizsgálható. Amíg nem voltak számítógépek, ezt grafikusan, 1:1 méretarányú hibaábrában végezték. Milliméterpapír közepén felrakták az M-jelú magaspontot és azon keresztül szögfelrakóval a magaspontra menố irányok irányszögeit. Az eredeti és az újramért törésszögek különbségeként lineáris eltéréseket képeztek, majd ezek értékével eltolták az eredeti irányokat, így kapták meg az új ponthelyet. Ha az eredeti és az új ponthely 2 centiméternél jobban különbözött, akkor elmozdultnak tekintették a pontot, és új koordinátát adtak neki (leolvasva a milliméterpapíron).

Ma számítógéppel, irány-és távméréses hálózatként, kiegyenlítéssel végezzük a számítást. Elôször a törzslapon szereplő adatokból, két adott pont alapján számítjuk a többi ôrpont koordinátáit (az 1. ábrán fekete tele kör jelöli az adott pontokat). Miután (két fordulóban) újramértük a törésszögeket (esetleg más ismert pontokra menố további irányokat), most az örpontok (mint adott pontok) alapján újraszámítjuk

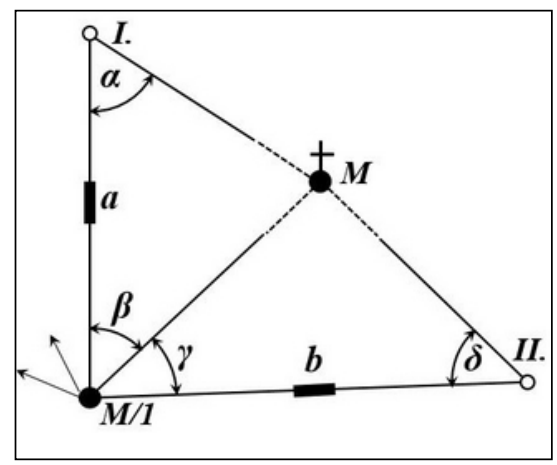

1. ábra. Magaspont (M) ôrhálózatának elvi vázlata a magaspont koordinátáit (2. ábra). A magaspont eredeti és új koordinátáinak különbségéből határozzuk meg a vízszintes értelmú elmozdulás mértéket. A magassági elmozdulást trigonometriai hálózatból vezetjük le.

Napjainkban új lehetôségünk is adódik az ôrhálózati mérések (így a fölös mérések) növelésére. Ha ugyanis a magaspont gömb (mint legtöbb esetben), akkor arra a mai távmérókkel (prizma nélküli módban) távolság is mérhetô (3. ábra). A gömb felszínére mért távolság a gömbsugár mértékével ugyan rövidebb lesz, de a sugár számítható. Ehhez elóbb - csak iránymérések alapján - számítjuk a gömbközéppont elôzetes koordinátáit, amiből az irány hossza kiszámítható. A gömb két szélére mért irányértékekbốl és az irány hosszából a gömbsugár levezethetô,

mindhárom álláspont esetében, azaz ellenôrzéssel. Kisebb többletmunkát jelent, hogy a gömböt ilyenkor 5 helyen kell irányozni, amit a fehérvári Széchenyi úti református templom és a gyepükajáni katolikus templom példáján mutatunk be (4. ábra).

A következôkben három közelmúltbeli saját példán mutatjuk be, hogy a magaspontok elmozdulásának vizsgálata során milyen tapasztalatokat szereztünk.

A gyepükajáni katolikus templom tornyát átépítették, ezért vált szükségessé koordinátáinak újbóli meghatározása. Mivel a levezetett pont is, és a két föld alatti őrpont is mérésre alkalmas állapotban megtalálható, az előzőekben leírt módszert követtük. Egyedüli problémát az jelentett, hogy a levezetett pont és a III-as ôrpont közé egy bokorsor

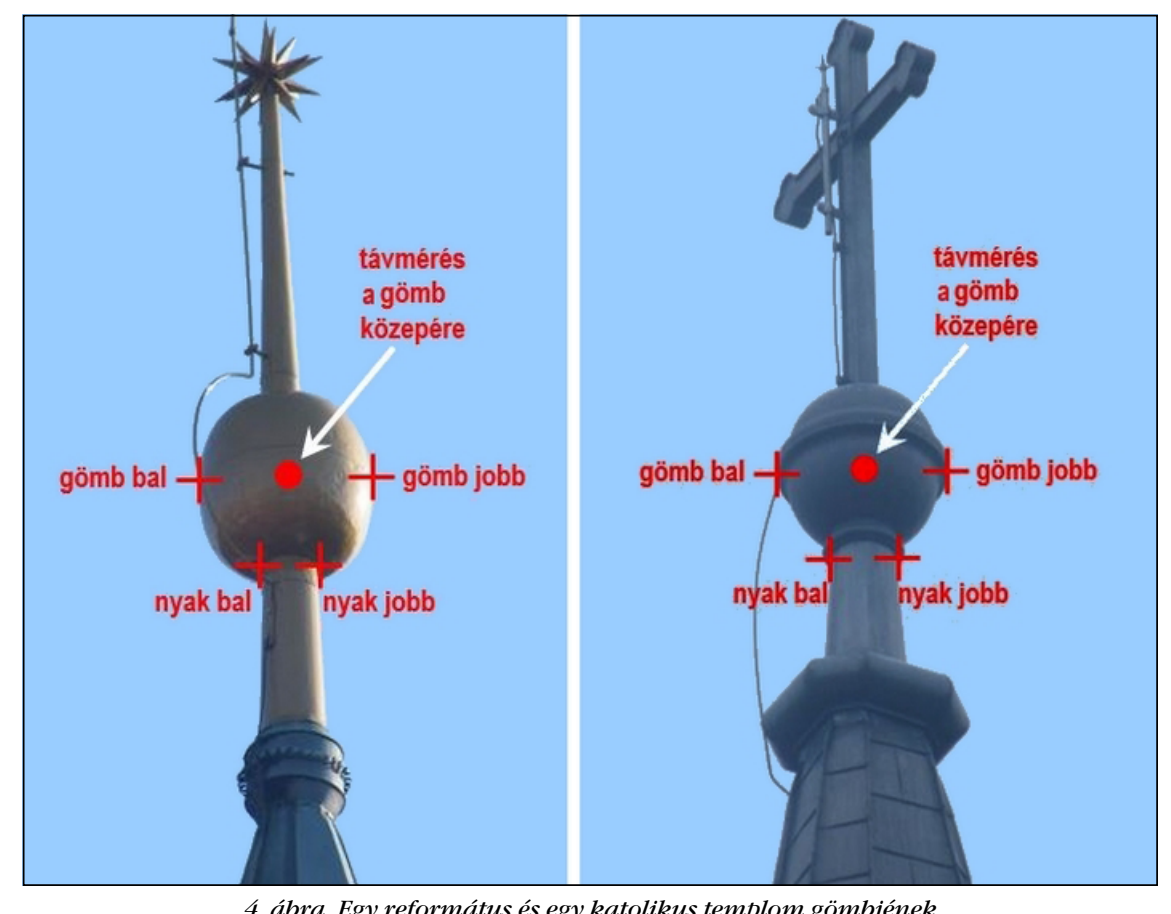

4. ábra. Egy református és egy katolikus templom gömbjének irányzási helyei, ha távolságot és mérünk rá

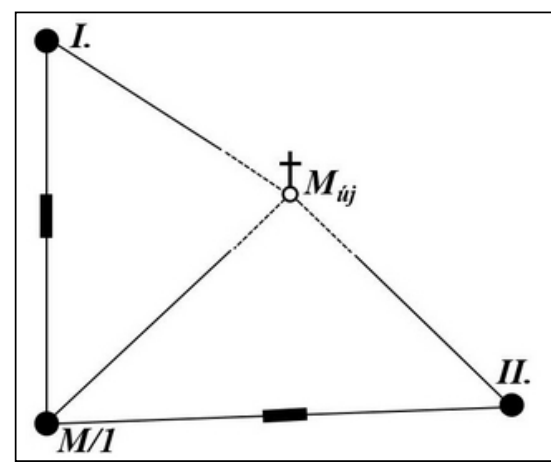

2. ábra. Az ôrhálózat újramérésének meghatározási vázlata

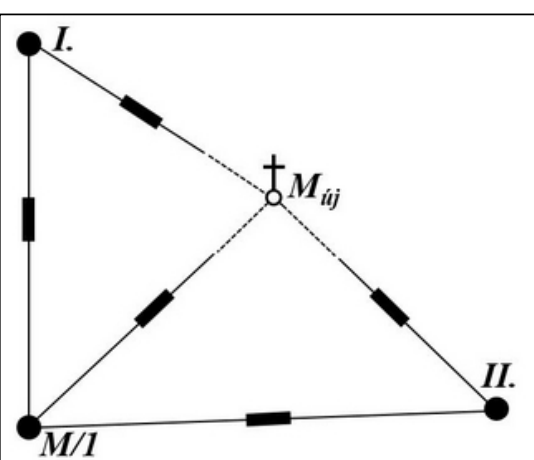

3. ábra. Ôrhálózat a magaspontra mért távmérésekkel kiegészítve 


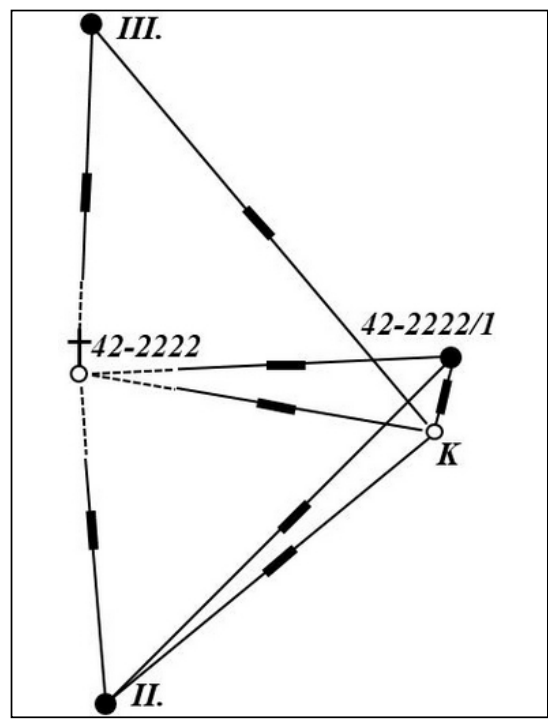

5. ábra. Meghatározási vázlat a gyapükajáni torony elmozdulásvizsgálatához

nôtt fel, így a két pont nem volt összemérhetô, emiatt egy K-jelú külponton (vesztett ponton) is történt irány- és távmérés (5. ábra). A méréseket kényszerközpontosan végeztük, ezért 4 múszerállványra volt szükség. A toronygömb közepére is mértünk távolságot a korábban leírtak szerint. A számítás a vízszintes hálózat majd a trigonometriai hálózat kiegyenlítésével történt, aminek több elônye van a szokásos pontkapcsolásokhoz képest. A vízszintes koordináták középhibái a két új pont (torony és külpont) esetében $2 \mathrm{~mm}$ alattiak. A koordinátaváltozások számszerú értékét a 2. táblázat tartalmazza.

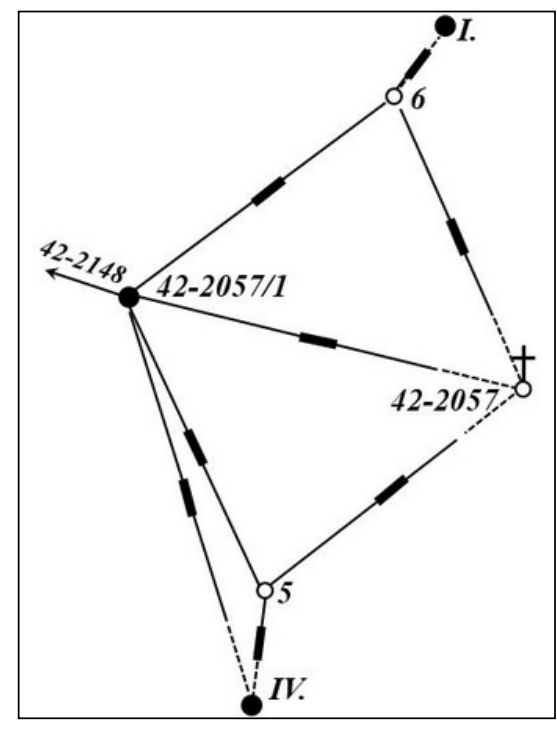

6. ábra. Meghatározási vázlat a csabrendeki torony elmozdulásvizsgálatához

Következô példánk a csabrendeki torony elmozdulásvizsgálata (6. és 7. ábra), amely az elôzốekben leírtak szerint, a toronygömbre végzett távolságmérések bevonásával történt. Itt a nehézséget az okozta, hogy bár a két ôrpont fizikailag létezik, de ezek álláspontként nem voltak használhatók. A IV-es számú ôrpontról a torony nem irányozható az idôközben megnôtt fák miatt. Az I-es számú ôrpont fölé kerítést emeltek, amit csak nagy üggyel-bajjal sikerült kibontani és külpontról irányozhatóvá tenni. Így két olyan külpont (a vázlaton 5 és 6 pontszámmal) kijelölésére került sor, ahonnan mind az

\begin{tabular}{|l|l|l|l|l|l|}
\hline település & pontszám & mérés éve & dy (EOV) & dx (EOV) & dM (Balti) \\
\hline Gyepükaján & $42-2222$ & 1992,2016 & $-0,06$ & $-0,14$ & $+0,13$ \\
\hline Csabrendek & $42-2057$ & 1992,2016 & 0,00 & $+0,04$ & $+0,35$ \\
\hline Nagycenk & $61-2051$ & 1984,2012 & $-0,06$ & $-0,11$ & $-0,12$ \\
\hline
\end{tabular}

2. táblázat. A példákban bemutatott magaspontok elmozdulásának értékei cm-ben

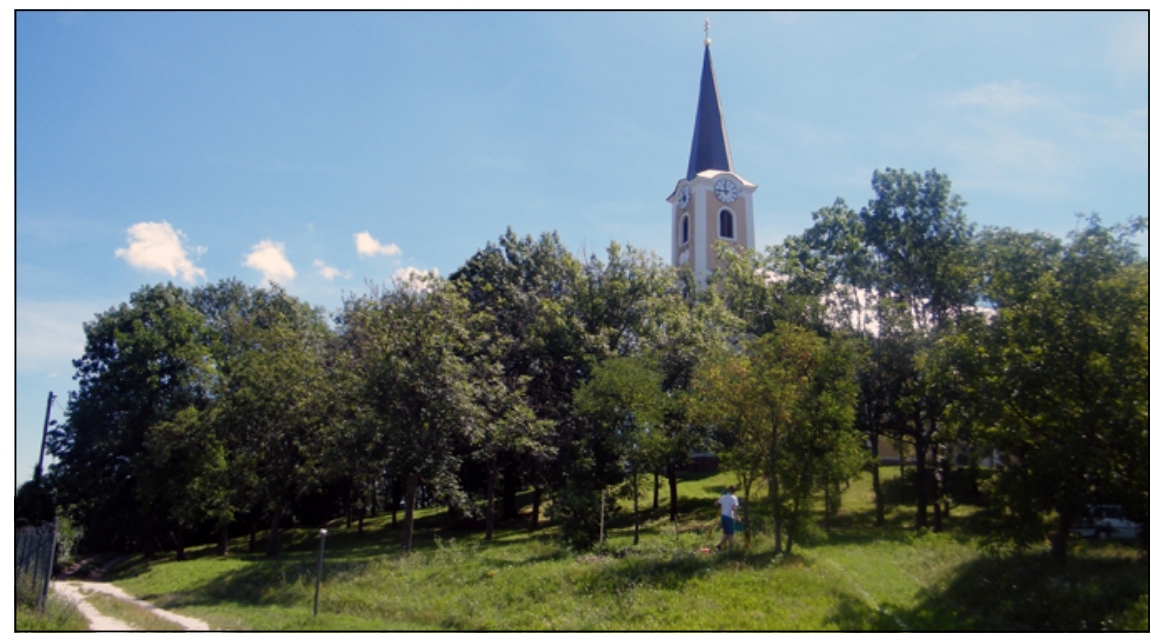

7. ábra. A csabrendeki torony környezete, elôtérben a levezetett ponttal

őrpont, mind a levezett pont és a torony is látható. Itt újra felhívjuk a figyelmet arra, hogy egy ilyen ôrhálózat hagyományos pontkapcsolásokkal nemigen számítható, csakis kiegyenlítéssel.

Következô példánk Nagycenk község Szent István-templomának elmozdulásvizsgálata. Ez a templom azért is híres, mert innen indult a "legnagyobb magyar", Széchenyi István temetési menete a közeli temetôben lévố családi kriptához (ami a Hídember címú film emlékezetes zárójelenete is). Az irodai előkészítés során egy nagyon gondosan készített 1984. évi ôrhálózatot volt módunk tanulmányozni, amelynek a szokásosnál jóval több, összesen 8 őrpontja van, és mindegyik EOVkoordinátáit már az eredeti meghatározáskor számították (8. ábra). Az ôrhálózat további érdekessége, hogy a toronytól a szokásosnál nagyobb távolságra helyezkednek el az ôrpontok, amit a beépítettség és a környezeti, domborzati viszonyok magyaráznak. Abban bíztunk, hogy találunk majd megfelelô számú ôrpontot a mérésekhez.

A helyszínre érve csalódnunk kellett, mert mindössze egyetlen ôrpontot (a VIII-as számút) találtunk meg. A pontpusztulás a Sopron-Szombathely vasútvonal átépítésével, az Arany-patak mederrendezésével és a templom körüli parkosítással magyarázható.

Maradt tehát a magaspontfelvezetés módszere, amikor elôbb a magaspont körül statikus GPS-méréssel határozunk meg alappontokat, majd ezen (adott) pontok felhasználásával, irányés távméréses mikrohálózatból adunk koordinátát a magaspontnak. Két-két GPS-pontot határoztunk meg a toronytól mintegy 150 méterre lévố nyugati és keleti sávban, követve az eredeti őrpontok helyszínét (9. ábra). A kétkét ôrpont közé egy-egy további álláspontot iktattunk be, így lényegében (klasszikus szóhasználattal) egy nyugati és keleti beillesztett sokszögvonalat hoztunk létre. A torony koordinátáit 6 meghatározó irányból, kiegyenlítéssel, 3 mm-es középhibával kaptuk meg.

Amire a konkrét eset kapcsán felhívjuk a figyelmet, az a GPS-EOV transzformációs megoldás. A 4 GPS-álláspont koordinátáit elsố körben VITELtranszformációból nyertük. Mivel a 26-os számú GPS-pont megegyezett a 


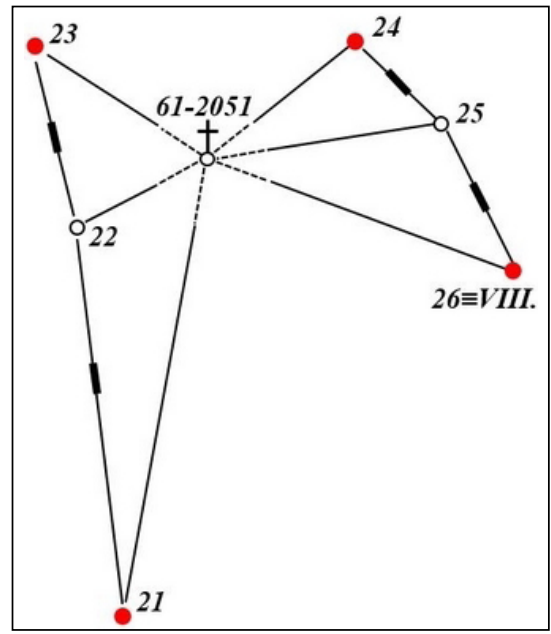

9. ábra. A nagycenki torony mikrohálózatának meghatározási vázlata, ahol a piros kör GPSméréssel meghatározott adott pontokat jelent

korábbi VIII-as ôrponttal, képezhetô volt az eredeti EOV-koordináták és a GPS-mérésből újonnan kapott koordináták különbsége: $\mathrm{dy}=1 \mathrm{~cm}, \mathrm{dx}=2 \mathrm{~cm}$, $\mathrm{dM}=4 \mathrm{~cm}$. Mivel ezt a kismértékú (elsôsorban a transzformációból eredő) hibát is el akartuk kerülni, a végleges transzformációt egy olyan lokális modell szolgáltatta, amelyben a program a maradék ellentmondásokat is figyelembe veszi, interpolálással az 1/t súlyozás szerint. Ebben az egyedi, lokális transzformációban a környező (a VITEL-lel megegyezô) OGPSH-pontok és a 26-os pont szerepeltek közös pontként. Így elértük, hogy a 26-os pont GPS-ból transzformált koordinátái pontosan egyeznek az eredeti értékkel.

\section{Levezetett pontok pótlása}

Amennyiben a magaspont levezetett pontját kell pótolni, általánosságban az ajánlható, hogy elsôsorban valamely ôrpont helyén, vagy az ôrhálózat felhasználásával tegyük ezt, mert így biztosítható a legjobb összhang az anyaponttal és kisebb költséggel jár a tisztán GPS-es megoldáshoz képest. A következőkben ezt az elvet is konkrét példákkal támasztjuk alá.

A zirci apátsági templom kettôs tornyaihoz tartozó levezetett pont a körforgalom építése miatt elpusztult. A helyszínelést követôen, hosszas mérlegelés után az egyik ôrhálózati pont szabványos kôvel történô újraállandósítását találtuk a legcélszerúbb megoldásnak (10. ábra). Ehhez a járda menti III-as ôrkövet le kellett süllyeszteni

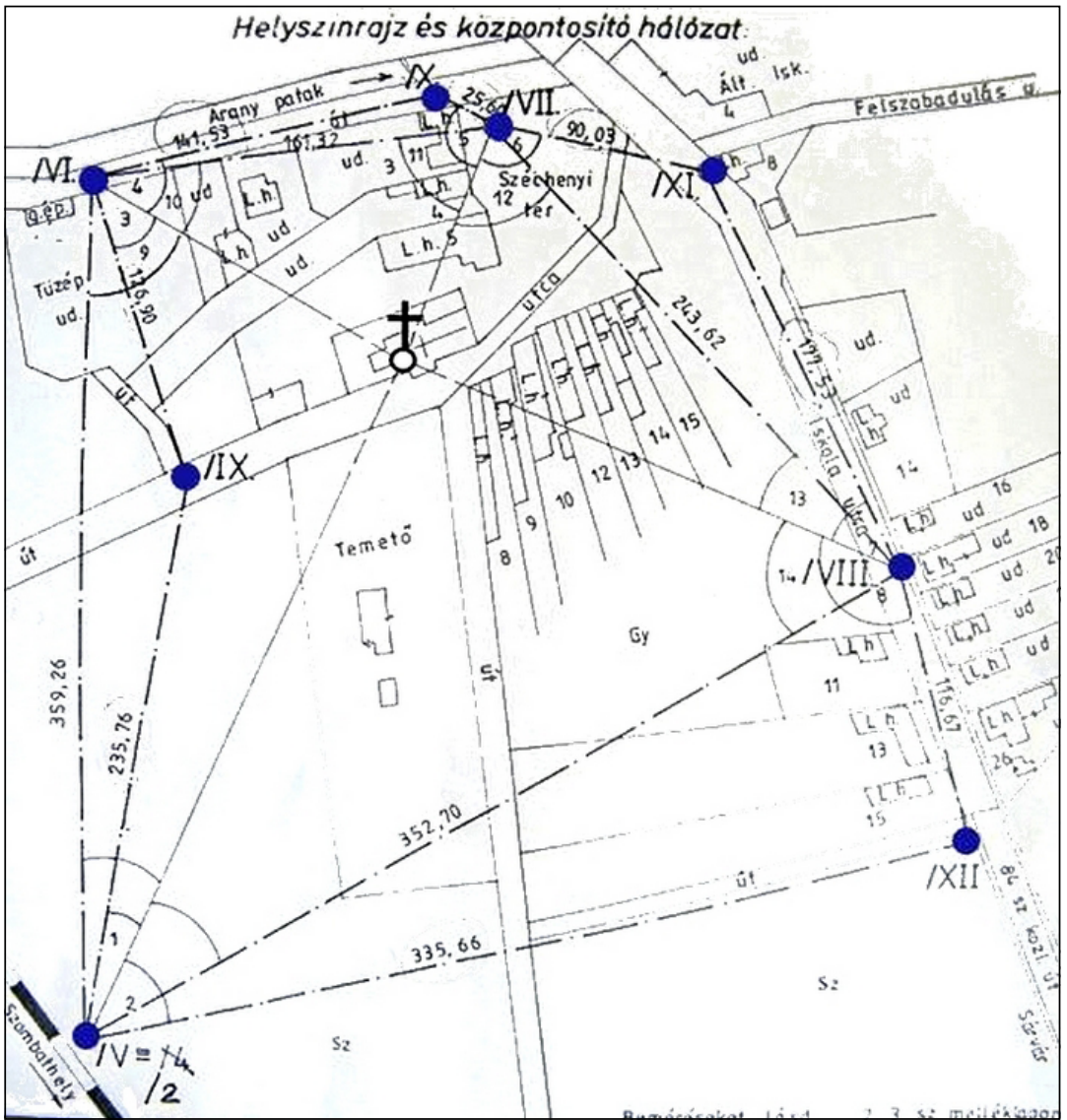

8. ábra. A nagycenki torony eredeti ôrhálózata

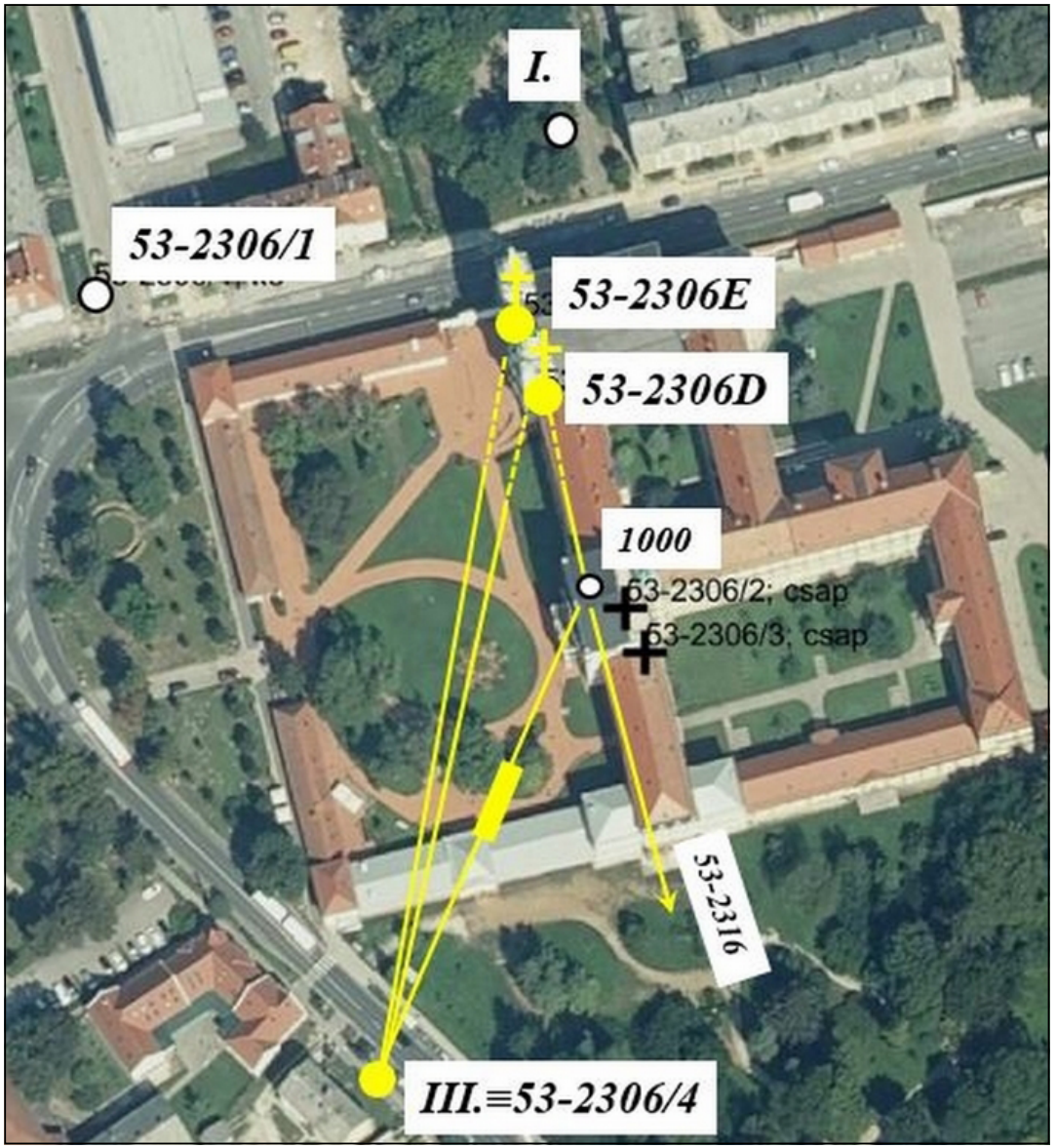

10. ábra. A zirci apátsági templom eredeti örpontjai és az ellenőrző hálózat 
és központosan, talajszintig sülylyesztve elhelyezni az új követ. Mivel eredetileg nem számoltak koordinátákat az ôrpontoknak, az új levezetett pont koordinátáit az egykori mérésekből számítottuk. Érdekesség, hogy a munkát ugyanazon kol-

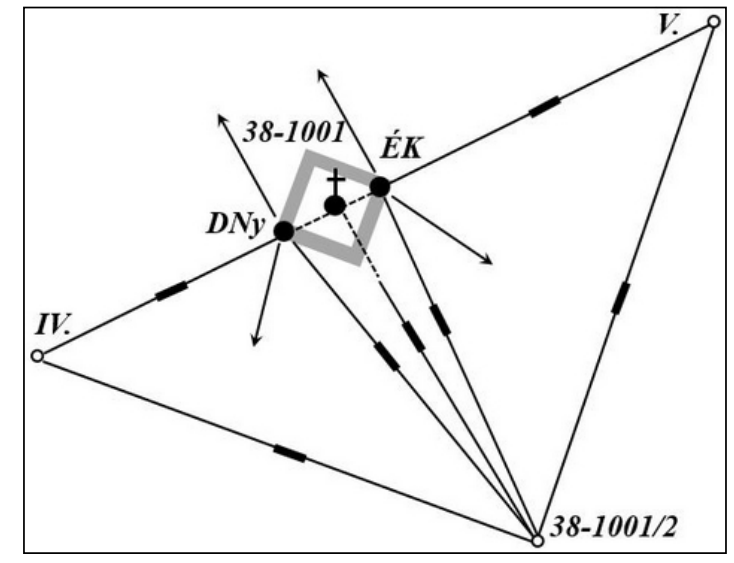

11. ábra. A kondorosi új ốrhálózat meghatározási vázlata légák végezték (a Pannon Geodézia munkatársai), akik az eredeti ôrhálózatot is mérték. További érdekesség, hogy az 1987-es ôrhálózatban az apátsági könyvtár tetején is volt egy / 2 jelû levezetett pont, majd GPS-méréssel egy $/ 3$ jelú alappontot is meghatároztak a tetôn, azonban a tetójavítások miatt ezek elpusztultak (az új pont száma így / 4 lett). A tetôn most is felálltunk a méróállomással (a vesztett pont száma 1000), ami ellenôrzô mérésre szolgált. Az ellenôrzố mérés azt mutatta, hogy az új levezetett pont a magaspontokkal összhangban van (ami az állandósítás központos voltát, kerethiba-mentességét és a magaspontok mozdulatlanságát igazolja).

Kondoros település evangélikus templomának tornyát 1952-ben elsôrendû́ alappontnak választották ki, számos dél-alföldi templomtoronyhoz hasonlóan. A templom melletti lelkészlakás falán emléktábla hirdeti, hogy 1938-ban itt született Balczó András, háromszoros olimpiai bajnok és tízszeres világbajnok öttusázó. A torony levezetett pontja közmúépítés miatt elpusztult, ennek pótlása a feladat. A helyszínelés során kiderült, hogy a két örpont sem használható, mert leaszfaltozták, így a pótlásra a GPS-technika tûnt megoldásnak. Adattári kutatás során tanulmányoztuk a torony törzskönyvét, amiből a következôket tudtuk meg. 1975-ben egy vihar következtében a toronysisak ledőlt, amit 1978-ban építettek újjá. Az újbóli geodéziai meghatározás érdekében 1979-ben szemlélték a tornyot és két pillér építését írták elő az erkélyen, valamint új ôrhálózat létesítését. A most elpusztult ôrhálózat tehát már a második a pont történetében, aminek mérését egyébként 1980-ban végezték. A torony (számunkra elốnyös) sajátossága, hogy a tetején körbejárható erkély van, és az 1980ban épített 1 méter magas pillérek ma is épek. A pillérek (ÉK, DNy) EOV-koordinátáit az eredeti mérések felhasználásával, kiegyenlítéssel számítottuk, és megterveztük az új ôrhálózatot (11. ábra). Itt is mértünk távolságot a toronygömbre, ami tovább növeli a fölös mérések számát. Az őrhálózat nagyon stabil, tájékozását a pillérekrôl a távoli alappontokra mért irányok biztosítják (a pontszámokat a zsúfoltság elkerülése érdekében a vázlaton nem tüntettük fel). A hálózat kiegyenlítése három változatban is elvégezhetô aszerint, hogy a vázlaton fekete körrel jelölt pontok közül (torony és két pillér) melyiket tekintjük adottnak: mindhármat; csak a tornyot; vagy csak a két pillért. E változatok az esetleges toronyelmozdulás vizsgálatára is alkalmasak. A kondorosi példa akkor is minta lehet, ha egy toronynak nincs erkélye, de a toronyablak alkalmas múszerálláspontnak.

A Fejér megyei Baracs község templomtornya több harmadrendú pont iránypontja volt, de koordinátáit és órhálózatát csak 1990-ben határozták meg. A levezetett pont és a torony közti irányszöget giroteodolittal mérték, mert a lapos, beépített területról nem látható tájékozó irány.

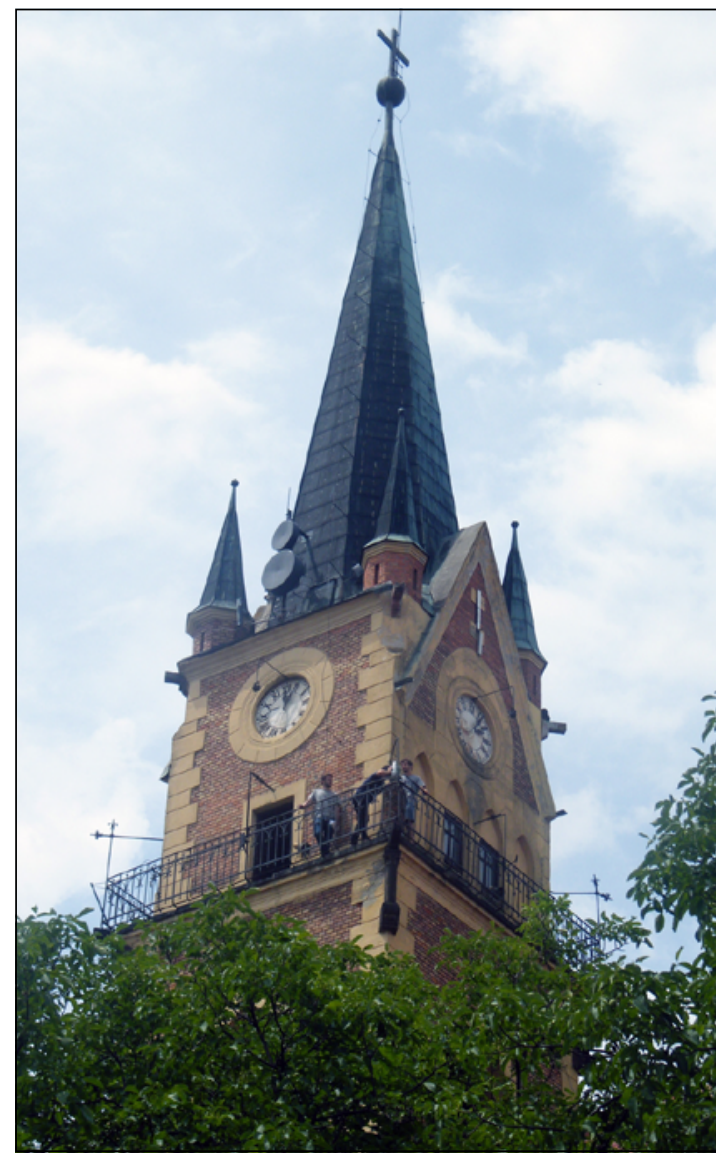

12. ábra. Mérés a kondorosi evangélikus templom erkélyén

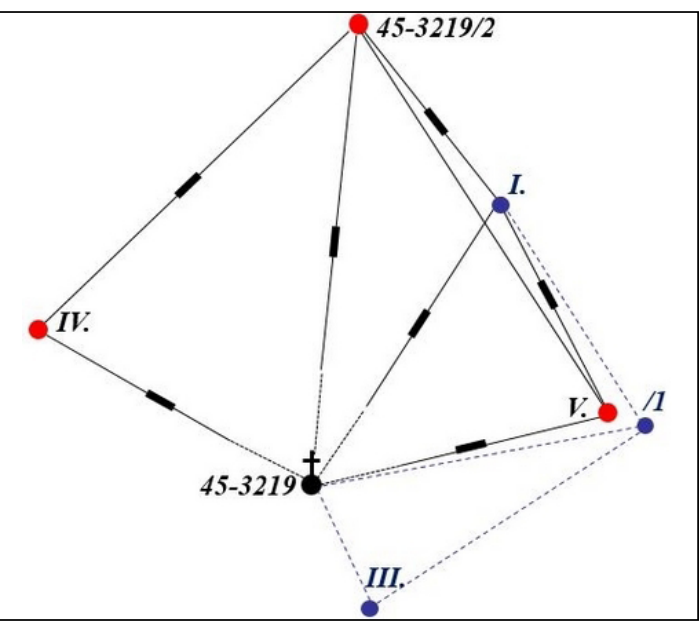

13. ábra. A baracsi torony régi (kék szinü) és új ôrhálózata

Kerékpárút építése miatt a /1 jelú levezetett pont a burkolat alá került, ezért vált szükségessé a pótlása, és ugyanilyen sorsra jutott a III-as ôrkő is, viszont az I-es ôrkövet megtaláltuk (a 13. ábrán kék színnel jelölve a régi oorhálózat). Ilyen esetben a GPS-technika az egyedüli megoldás a pontpótlásra. Az új, /2 jelú levezetett pontot két OGPSH-pont és két referenciaállomás (PAKS, DUJV) alapján, gyors statikus méréssel határoztuk meg. Egyedüli dilemmát az aktív, 
illetve a passzív GNSS-hálózat inhomogenitásának gyanúja okozott. Ugyanis, ha csak OGPSH-pontok alapján, vagy csak referenciaállomások alapján számítunk (transzformálunk) koordinátákat, akkor a keleti (y) koordinátákban $3 \mathrm{~cm}$ eltérést tapasztalunk.

Itt egy új ôrhálózatot is létesítettünk, 3 GPS-pontra alapozva. A példában azt mutatjuk be, milyen lehetôségünk adódik az új ôrpontok és a torony (illetve az I-es ôrpont) összhangjának ellenôrzésére.

- A / 2 pont és a torony (illetve I-es ôrpont) távolságának összehasonlítása, távolságeltérések kimutatása.

- Irányeltérések kimutatása a /2 ponton végzett tájékozásból.

- A torony koordinátáinak számítása a GPS-es hálózatból és összehasonlítása az eredeti koordinátákkal.

- Szabad hálózat kiegyenlítése (a torony koordinátáinak és a toronylevezetett pont irányszögének megkötésével), majd a koordináták összehasonlítása.

\section{Új magaspontok meghatározása}

Pákozd település és az M7-es autópálya között található a Bogár-domb, egy természetes, gránitsziklás kiemelkedés, amelyen 1971-ben egy negyedrendú alappontot (54-2442) telepítettek, vasbetonlapos védmúvel. Ezt a dombot nézte ki magának egy vállalkozó, aki eredeti szándéka szerint a világ legmagasabb ólomkatona szobrát kívánta itt felállítani. A tervból végül (2017-ben) egy 12,5 méter magas Miska huszár szobor lett, emléket állítva a magyar huszárság világraszóló tetteinek. A szobor vasbetonból készült, egy elốre elkészített öntôforma szintenkénti kiöntésével. A nyolcszög alakú lépcsôs talapzathoz 100 tonna vasbetont használtak fel. Miska huszár jobb kezében nemzeti színú zászlót tart, bal kezével kardra támaszkodik, s arra néz, amerrôl a nevezetes pákozdi csata idején az ellenség érkezett.

Kézenfekvố volt, hogy a pontpótlás során magaspontként határozzuk meg a szobor egyértelmú irányzásra alkalmas pontját, nevezetesen a zászlórúd fémcsövének tetejét. Levezetett pontként a talapzatba fúrt fémcsap szolgál. A magaspont-felvezetés módszere szerint egy négy pontból álló, kényszerközpontosan mért mikrohálózatot létesítettünk a szobor körül (15. ábra), ennek három pontja föld alatti őrkő, a negyedik vesztett pont. Az ôrpontok koordinátáit gyors statikus GPS-mérésből kaptuk; ismételt pontraállást végezve a két húszperces mérési periódus között. Megjegyzés: az utófeldolgozás során derült ki, hogy a korábban sokszor használt sukorói 54-2429 OGPSH-pont köve megdôlt, így nem használható. A vízszintes hálózat kiegyenlítésekor csak egyetlen GPS-pont koordinátáit használtuk adott pontként (piros színnel jelölve az ábrán), mert minden álláspontról számos távoli alappontra történt iránymérés, így ezekkel az irányokkal a hálózat tájolása, beillesztése a környezetbe jobban biztosítható. A magaspont és az új pontok koordináta-középhibái 3 mm-esek. A trigonometriai magassági hálózatban (egy adott pontra építve) is $1 \mathrm{~cm}$ alattiak a középhibák és a javítások. A törzslap szög- és távolságadatait a hálózat szabad hálózati kiegyenlítésébôl kaptuk.

Székesfehérvár legmagasabb pontján, az Öreg-hegyen 1994-ben építették meg a Szent Donát-kápolnát, a második világháborúban bombatalálatot kapott, a korábban évszázadokon át itt álló, hasonló titulusú kápolna újjáépítéseként. Az építkezés során elpusztult egy negyedrendú vízszintes alappont, ennek pótlásaként merült fel az új kápolna tornyának meghatározása magaspontként. A toronyhoz ôrhálózat is létesült (16. ábra), ennek egyik pontja a terepszinti levezetett pont, amelyet gondos mérlegelés után (a hosszú távú fennmaradást elsốdlegesnek tekintve), egy parkoló sarkánál állandósítottunk. Az ôrhálózat pontjait statikus GPS-méréssel határoztuk meg, az OGPSH-pontokon kívül bevonva a térbeli hálózatba a közeli vízszintes alappontokat is. Ajánlásként fogalmazható meg, hogy ha a legjobb helyi illeszkedést kívánjuk elérni a

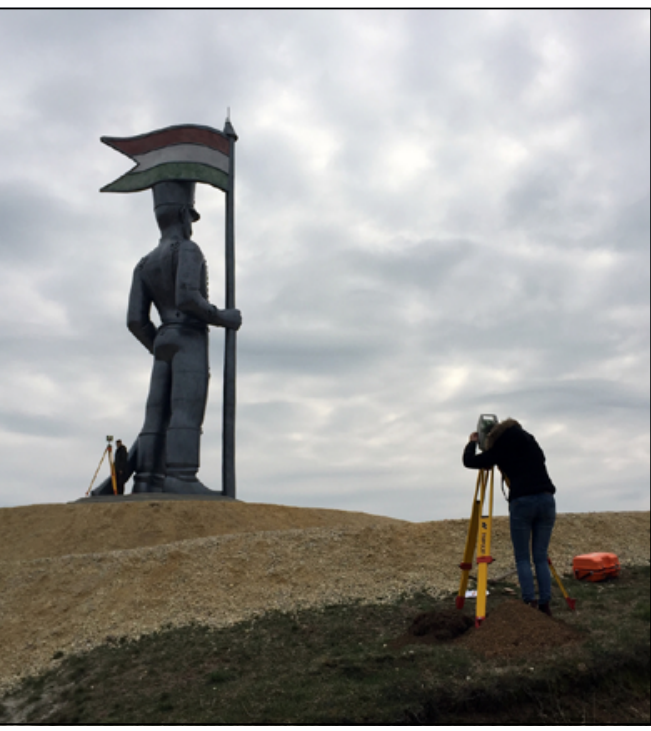

14. ábra. Ôrhálózat mérése Miska huszár szobránál

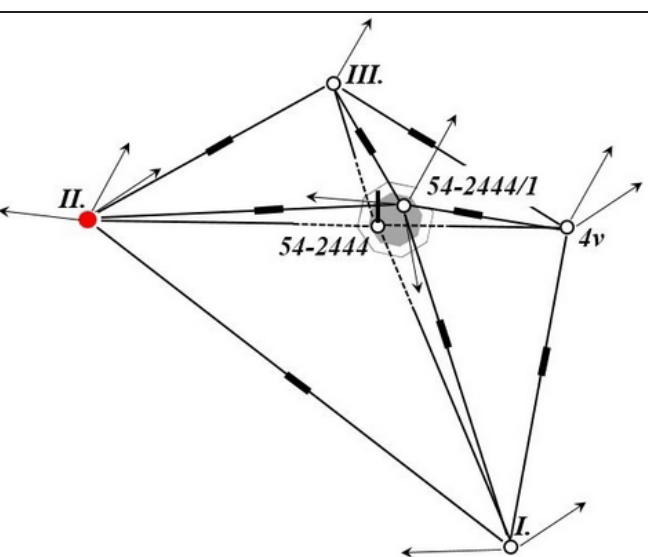

5. ábra. Miska huszár szobrának, mint magaspontnak a meghatározási vázlata

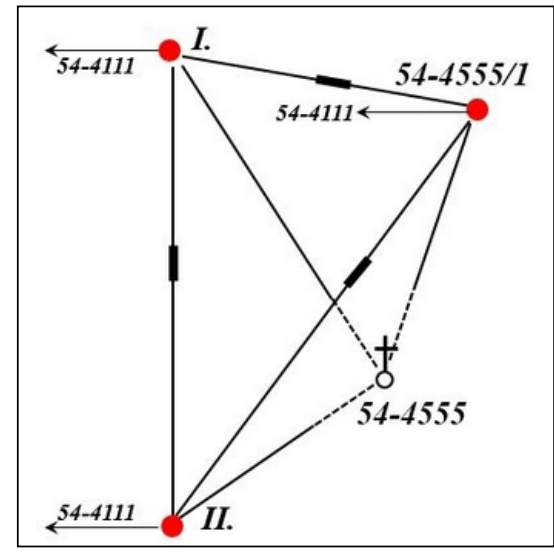

16. ábra. A fehérvári Szent Donát-kápolna meghatározási vázlata

GPS-hálózat és az EOVA között, akkor egyedi transzformációs paramétereket számítsunk, és ezeket a pontokat is vonjuk be közös pontként (ahogyan azt a nagycenki torony példáján is láttuk). A Szent Donát-kápolna Székesfehérvár egészen távoli (több tíz kilométeres) környezetéből is jól látható, magasan 


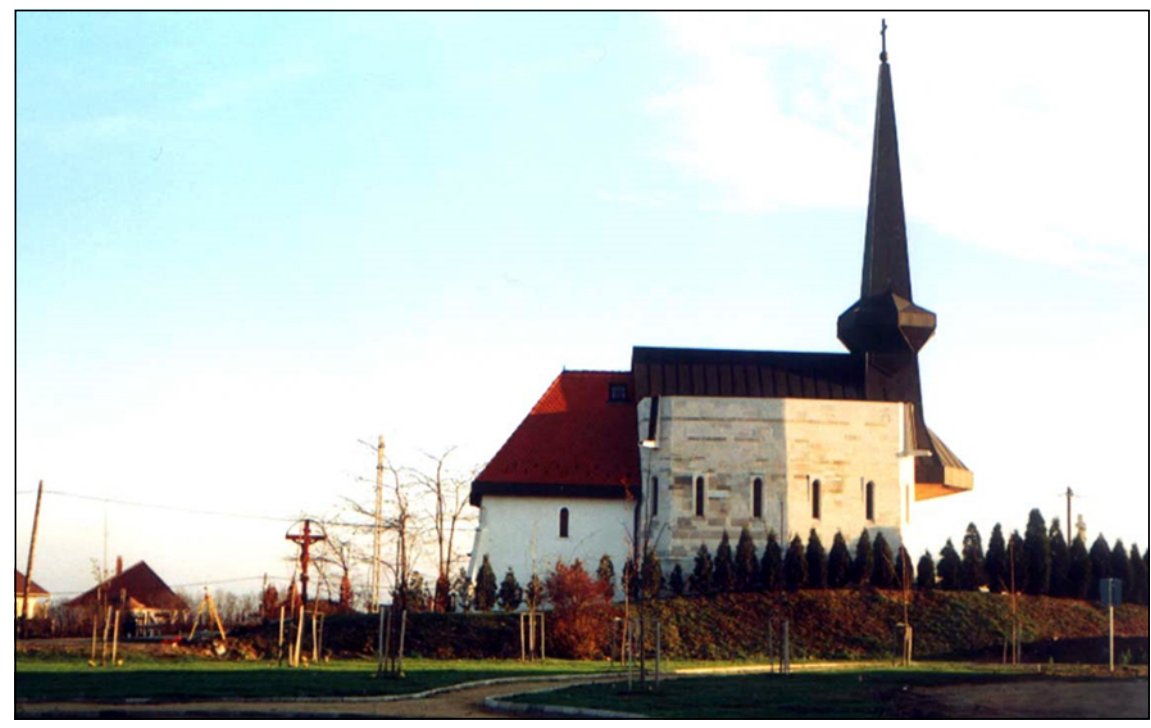

17. ábra. A Szent Donát-kápolna (bal sarokban a levezett ponton álló GPS-vevô)

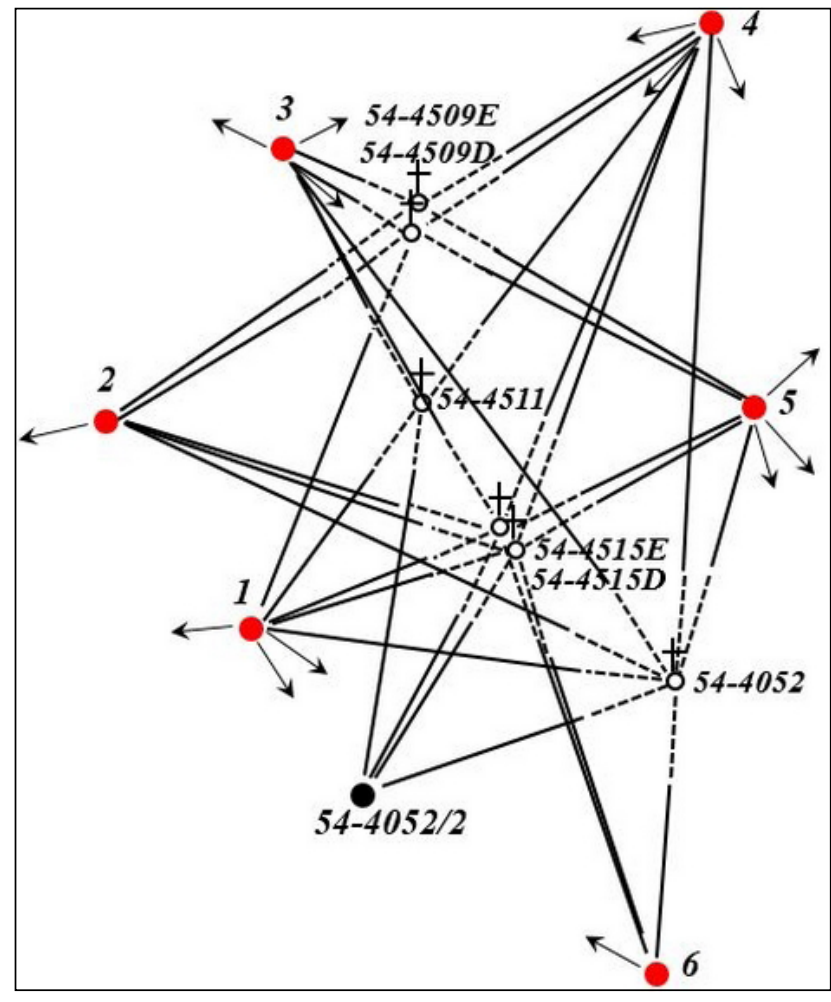

18. ábra. Hat fehérvári belvárosi torony meghatározási terve magaspont-felvezetéssel (a GPS-álláspontok a piros tele körök) sokszögvonalakról, amelyek álláspontjai többnyire tízemeletes lapos tetôs épületek tetején helyezkedtek el. Az új méréskor is épüleki álláspontokat (például az Alba Pláza tetôparkolójában, a megyei földhivatal tetején, a ciszter gimnázium tetején), de ezeket statikus GPS-méréssel határoztuk meg (18. ábra). Az álláspontokról megfelelố számú tájékozó irány és az összes új pont látható. A 18. ábra tisztán irányméréses meghatározó irányokat jelez, de olyan meghatáro-

kiemelkedik a város sziluettjéból, ugyanakkor a kápolna terepszintjérôl csak egyetlen tájékozó pont (a Videoton kéménye) mérhetô, mivel az épület egy lapos platón helyezkedik el, és mára teljesen beépített lett.

Utolsó példánk Székesfehérvár belvárosi templomtornyainak újbóli meghatározásáról szól. Ezeket a tornyokat 1971-ben a fehérvári fớiskola (GEO) oktatói határozták meg negyedrendû alappontként, mégpedig tisztán irányméréssel, olyan hosszú oldalú távolságot is mértünk A magaspont felvezetésbôl kapott koordináták és az eredeti koordináták között legfeljebb 1 cm eltérés volt, kivéve a bazilika déli tornyát, amelyrốl már korábban is kiderült, hogy elmozdult.

\section{Összefoglalás}

Írásunkban a magaspontok és ôrhálózatuk ellenôrzésére, pótlására mutattunk be a gyakorlatból vett példákat. tek tetején jelöltünk

A magaspontra, prizma nélküli módban végzett távmérések növelik a fölös adatok számát, illetve kevesebb adott pontból teszik lehetôvé az újbóli meghatározást. A levezetett pontok pótlásakor elsódlegesen a meglévő ôrhálózatra érdemes támaszkodni. A GPS-technikával történố pontpótláskor az egyedi, helyi transzformációs paraméterek számítására hívtuk fel a figyelmet. Új magaspontokat a magaspont-felvezetés módszerével érdemes meghatározni, a helyi sajátosságokat figyelembe véve.

\section{Irodalom}

Busics György - Csepregi Szabolcs 1992. Hálózati szemlélet a vízszintes alappontsû́rítésben. Geodézia és Kartográfia, 44. évf. 3. sz. pp. 157-166.

Busics György 1995. A magaspontok és a GPS Geodézia és Kartográfia, 47. évf. 4. sz. pp. 201-209.

Busics György 2005. Alappontmeghatározás. NYME GEO főiiskolai jegyzet, Székesfehérvár, p. 200

Földváry Szabolcsné 1989. Alaphálózatok II. BME egyetemi jegyzet. Tankönyvkiadó, Budapest.

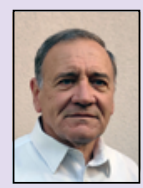

\section{Dr. Busics György}

c. egyetemi tanár

Óbudai Egyetem Alba Regia Múszaki Kar, Székesfehérvár busicsgy@gmail.com

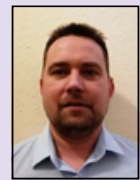

\section{Dr. Tóth Zoltán} egyetemi docens

Óbudai Egyetem Alba Regia Múszaki Kar, Székesfehérvár toth.zoltan@amk.uni-obuda.hu 